\title{
A Novel Citrus Rootstock Tolerant to Iron Deficiency in Calcareous Soil
}

\author{
Lina Fu and Lijun Chai \\ Key Laboratory of Horticultural Plant Biology, Ministry of Education, Huazhong Agricultural \\ University, Wuhan, China; and Key Laboratory of Horticultural Crop Biology and Genetic \\ Improvement (Central Region), Ministry of Education, Wuhan, China
}

Dekuan Ding

Key Laboratory of Horticultural Plant Biology, Ministry of Education, Huazhong Agricultural University, Wuhan, China; Key Laboratory of Horticultural Crop Biology and Genetic Improvement (Central Region), Ministry of Education, Huazhong Agricultural University, Wuhan, China; and Chenggu Fruit Industry Technical Guidance Station, Shaanxi, China

Zhiyong Pan ${ }^{1}$ and Shu'ang Peng ${ }^{1}$

Key Laboratory of Horticultural Plant Biology, Ministry of Education, Huazhong Agricultural University, Wuhan, China; and Key Laboratory of Horticultural Crop Biology and Genetic Improvement (Central Region), Ministry of Education, Wuhan, China

ADDiTIONAL INDEX wORDs. Fe deficiency, ferrous Fe, gene expression, 'Miyagawa Wase' Satsuma mandarin, trifoliate orange, 'Zhique'

\begin{abstract}
Iron (Fe) deficiency caused by calcareous soil is a serious problem in the cultivation of citrus (Citrus L.) trees. In this study, we report that 'Zhique' (Citrus wilsonii Tanaka) citrus rootstock from Chenggu county of Shaanxi province, China, shows tolerance to Fe deficiency under calcareous soil conditions. In the same calcareous field conditions, 'Miyagawa Wase' Satsuma mandarin (Citrus unshiu Marc.) grafted on trifoliate orange [Poncirus trifoliate (L.) Raf.] rootstock, the most commonly used rootstock, showed obvious interveinal chlorosis in young leaves, though some leaves or branches are asymptomatic, whereas no symptoms were found on those grafted on 'Zhique' rootstock. This was further evidenced by the fact that the chlorophyll concentration in chlorotic leaves of 'Miyagawa Wase' grafted on trifoliate orange was significantly lower than in those grafted on 'Zhique'. In addition, transmission electron microscopy (TEM) analysis revealed a significant reduction of grana and stroma thylakoid of chloroplasts in chlorotic leaves. Measurement of Fe concentrations revealed that the total Fe and cell wall Fe showed no difference between 'Zhique' and trifoliate orange roots, whereas the ferrous Fe was significantly higher in ' $Z$ hique' than trifoliate orange roots. Interestingly, both total $\mathrm{Fe}$ and ferrous $\mathrm{Fe}$ concentrations in chlorotic leaves were significantly lower than in green leaves of 'Miyagawa Wase' grafted on either 'Zhique' or trifoliate orange, whereas the cell wall Fe concentration of 'Miyagawa Wase' leaves only showed significant difference between the 'Zhique' and trifoliate orange samples. Further transcript assessment found that the Fe acquisition-related genes FIT, HA, FRO, and $N R A M P$ were upregulated in roots of 'Zhique' compared with trifoliate orange, thus suggesting 'Zhique' might be more capable of $\mathrm{Fe}$ uptake under calcareous soil conditions. The novel citrus rootstock reported here could be used as an ideal material for Fe-uptake research, and as a Fe-deficiency-tolerant rootstock for citrus cultivation in calcareous soils.
\end{abstract}

Iron is an essential micronutrient for all plants because it takes part in many important cellular activities, including chlorophyll biosynthesis, respiration, and nitrogen $(\mathrm{N})$ assimilation, among others. In chloroplasts, $\mathrm{Fe}$ is essential for photosynthetic electron transport and it functions as a cofactor for superoxide dismutases; Fe deficiency results in decreased concentrations of photosynthetic pigments and other components of the thylakoid membrane (Morales et al., 1991, 1994). Thus, Fe homeostasis is critical for chloroplast and plant development. Fe is extremely insoluble in alkaline soils, as it

Received for publication 22 Sept. 2015. Accepted for publication 14 Dec. 2015. This research was financially supported by the National Modern Agriculture (Citrus) Industry System of Special Funds (CARS-27); the National Natural Science Foundation of China (No. 31471841); the Special Fund for Agroscientific Research in the Public Interest (No. 201303093); and the Ministry of Agriculture of China (No. 201203075).

${ }^{1}$ Corresponding author. E-mail: zypan@mail.hzau.edu.cn or shuangpeng428@126. com. often precipitates with phosphates or hydroxyl ions. It is believed that an appropriate soil $\mathrm{pH}$ range $(\mathrm{pH} 5.5-6.5)$ is crucial for $\mathrm{Fe}$ availability in citrus cultivation, and the Fe availability would decrease along with the increase of the soil $\mathrm{pH}$ values (Obreza and Morgan, 2008). Fe deficiency in alkaline soils has become a serious problem in crop cultivation worldwide. Fe deficiency not only affects plant vegetative growth but also causes yield and quality losses in crop production (Àlvarez-Fernàndez et al., 2006; Fageria et al., 2002; Rashid and Ryan, 2004).

Understanding the mechanisms of $\mathrm{Fe}$ uptake is a prerequisite for the diagnosis and mitigation of Fe-deficiency chlorosis in crop plants. Plants have two strategies for Fe uptake: strategy I depends on the reduction of ferric $\mathrm{Fe}$ in dicotyledon and nongrass monocotyledon plants, and strategy II relies on releasing siderophore to promote $\mathrm{Fe}$ absorption (Kim and Guerinot, 2007; Römheld and Marschner, 1986; Schmidt, 1999). The molecular mechanisms of Fe uptake for strategy I have been widely studied in nongrass monocotyledon plants. It 
is well documented that Fe is first solubilized by $\mathrm{H}^{+}$-ATPasedriven ( $H A$ gene family) excretion of protons in the rhizosphere of roots (Dell'Orto et al., 2000); it is then reduced by ferric chelate reductase encoded by the $F R O$ gene family in the apoplast (Robinson et al., 1999), and finally enters the symplast through the Fe-regulated IRT transporters (Barberon et al., 2011). In addition, the integral membrane NRAMP proteins function as broad-specificity ferrous metal ion transporters in plants (Curie et al., 2000; Kaiser et al., 2003), thus they play an important role in intracellular Fe homeostasis (Clemens, 2001). Regarding strategy II, ferric Fe, which binds with high affinity chelators phytosiderophores, is taken up by a transporter of the yellow stripe family (Nozoye et al., 2011).

Citrus is one of the most important fruit crops worldwide, but Fe deficiency often occurs when citrus is grown in calcareous soils (Tagliavini and Rombolà, 2001). Fertilization is usually used to supply adequate amounts of soluble Fe for crops (Bacaicoa and García-Mina, 2009; Rombolà and Tagliavini, 2006; Shenker and Chen, 2005); however, overfertilization not only increases economic costs but also damages ecosystems. Selecting and developing Fe-deficiency-tolerant rootstocks could be an effective and environmentally friendly strategy to address the Fe chlorosis issue in the citrus industry (Castle et al., 2009; Licciardello et al., 2013; Pestana et al., 2005).

In this study, we studied the performance of a novel rootstock, 'Zhique', in calcareous soil conditions. 'Zhique' is a local citrus rootstock native to Chenggu county of Shaanxi province, China. In the same orchard with calcareous soil, 'Miyagawa Wase' Satsuma mandarin grafted on 'Zhique' displayed normal growth, but those grafted on the most commonly used rootstock, trifoliate orange, showed typical chlorosis. To understand possible mechanisms of 'Zhique' rootstock tolerant of Fe deficiency, Fedeficiency chlorosis symptoms of the same 'Miyagawa Wase' Satsuma mandarin scion on different rootstocks in calcareous soil were measured. We examined soil properties and physiological parameters in plants, such as leaf nutrition, chlorophyll concentration, Fe concentrations in plants, and the transcription expression of Fe-uptake-related genes to provide possible insights into the occurrence of Fe deficiency.

\section{Materials and Methods}

Plant materials ANd growth conditions. The experiment was conducted in July 2014 in an orchard in the Chenggu county of Shaanxi province, China (lat. $33^{\circ} 03^{\prime} \mathrm{N}$, long. $107^{\circ} 01^{\prime} \mathrm{E}, 500 \mathrm{~m}$ elevation). The citrus cultivar was 20 -yearold 'Miyagawa Wase' Satsuma mandarin trees grafted on 'Zhique' and trifoliate orange rootstocks. Field cultural practices were applied uniformly to all citrus trees. Six representative trees were chosen from 'Miyagawa Wase' grafted on trifoliate orange and 'Zhique' rootstocks, respectively. Since parts of leaves or branches of 'Miyagawa Wase' grafted on trifoliate orange were asymptomatic, two leaf samples of the green leaves and chlorotic leaves in the 'Miyagawa Wase' trees grafted on trifoliate orange, and one leaf sample of the green leaves in 'Miyagawa Wase' trees grafted on 'Zhique', were collected from nonfruiting, spring branches of six chosen trees. Each leaf sample consisted of $\approx 100$ leaves randomly collected around the dripline of the plants. Root samples were also sampled correspondingly from the selected 12 'Miyagawa Wase'. Samples from two trees were combined into one replicate.
Each soil sample was collected from a single soil core of the tree as mentioned above (a total of 12 trees) at the drip line (80$100 \mathrm{~cm}$ from the trunk) with $20 \mathrm{~cm}$ deep. The soil samples were air-dried at room temperature, triturated with a wooden roller, then passed through a 1-mm sieve and stored in sealing bag after homogenization. The parameters of the soil samples $(\mathrm{pH}$, organic matter, $\mathrm{N}, \mathrm{P}, \mathrm{K}, \mathrm{Ca}, \mathrm{Mg}, \mathrm{Fe}, \mathrm{Mn}, \mathrm{Cu}, \mathrm{Zn}$, and $\mathrm{B}$ ) and leaf tissue samples (N, P, K, Ca, Mg, Fe, Mn, Cu, Zn, and B) were measured according to the soil and agricultural chemistry analysis as reported by Bao (2000).

TEM OF THE CHLOROPLAST ULTRASTRUCTURE. Small leaf sections were washed with phosphate-buffered saline $(\mathrm{pH} 7.2)$ at room temperature and postfixed in $2 \%(\mathrm{w} / \mathrm{v})$ osmium tetroxide in phosphate-buffered saline $(\mathrm{pH} \mathrm{7.2)} \mathrm{for} 3 \mathrm{~h}$; then they were rinsed twice in phosphate-buffered saline and stained with uranyl acetate. Samples were dehydrated by passing them through a series concentration of ethanol and acetone, and then embedded in epoxy resin (Agar 100; Agar Scientific, London, UK). Samples were cut, treated with uranyl acetate/lead citrate, and observed with a transmission electron microscope (Tecnai G2 Spirit; FEI, Columbia, MD).

Determination of Chlorophyll CONCENTRATION. Fresh leaf tissue $(200 \mathrm{mg})$ was cut into small pieces with scissors, and pigment was extracted by grinding with a mortar and pestle for $5 \mathrm{~min}$ in $10 \mathrm{~mL}$ of $80 \%$ acetone : $95 \%$ ethanol $(1: 1)$. The supernatant was then transferred into a new $15-\mathrm{mL}$ centrifuge tube, and incubated with $80 \%$ acetone: $95 \%$ ethanol $(1: 1)$ for $24 \mathrm{~h}$ in the dark. Optical density (OD) of the extracted samples was measured at both 663 and $644 \mathrm{~nm}$. The concentration of chlorophyll ( $\mathrm{Chl}$ a and $\mathrm{Chl} \mathrm{b})$, in milligrams per gram of fresh weight $(\mathrm{FW})$ tissue, was calculated by the following formulas:

$$
\begin{aligned}
\text { Milligrams chlorophyll a/g }(\mathrm{FW})= & 1.07\left(\mathrm{OD}_{663}\right) \\
& -0.094\left(\mathrm{OD}_{644}\right) \\
\text { Milligrams chlorophyll b/g }(\mathrm{FW})= & 1.77\left(\mathrm{OD}_{644}\right) \\
& -0.280\left(\mathrm{OD}_{663}\right)
\end{aligned}
$$

Determination of Fe concentration. Total Fe concentration and ferrous Fe concentration in root and leaf samples were extracted by two different methods. Total Fe concentration was measured as followings: the dry sample $(0.30 \mathrm{~g})$ was dry-ashed at $500{ }^{\circ} \mathrm{C}$ for $24 \mathrm{~h}$, followed by dissolution in $1 \mathrm{M} \mathrm{HCl}$ (Storey and Treeby, 2002). Ferrous Fe was extracted according to the method of Oserkowsky (1933), as modified by Llorente et al. (1976), where dry samples (1 g) were digested with $1 \mathrm{M} \mathrm{HCl}$. Both the total Fe concentration and ferrous Fe concentration of the dissolved solutions were measured using an atomic absorption spectrophotometer (Z2000; Hitachi, Tokyo, Japan).

Determination of Cell wall Fe concentration. Cell wall was extracted from roots and leaves as described by Ishii et al. (1999) where $\approx 3 \mathrm{~g}$ of samples were ground in a fine powder. The pellet was then washed three times with $30 \mathrm{~mL}$ of $80 \%$ ethanol, and $100 \%$ ethanol was added to rinse the samples again, centrifuging between each wash. The homogenate was centrifuged for $5 \mathrm{~min}$ at $3889 \mathrm{~g}$. The resulting supernatant was rinsed in the $100 \%$ ethanol. The pellet was incubated for $1 \mathrm{~h}$ at $25{ }^{\circ} \mathrm{C}$ in $30 \mathrm{~mL}$ of chloroform:methanol (1:1) solution. Following centrifugation, the supernatant was discarded and the residue was resuspended in $30 \mathrm{~mL}$ acetone. After centrifugation, the residue was dried for further measurement of cell wall $\mathrm{Fe}$ 
concentration. Fe concentration of cell wall was measured according to the total Fe concentration measurement described above.

RNA EXTRACTION AND REAL-TIME REVERSE TRANSCRIPTION POLYMERASE CHAIN REACTION (RT-PCR). Root samples were used for RNA isolation. Total RNA was isolated from samples according to instructions from the manufacturers of trizol reagent (RNAiso Plus; Takara, Dalian, China). RNA quality $\left(\mathrm{OD}_{260}\right.$ : $\mathrm{OD}_{280}$ ) and concentration were measured. The mRNA of all the samples was adjusted to an equal concentration to avoid possible bias in transcript evaluation. The specific primers of targeted genes for quantitative RT-PCR are provided in Supplemental Table 3. The Actin gene was used as an internal reference between different samples. Quantitative RT-PCR reactions were performed with the SYBR Green PCR Master Mix (SYBR Premix Ex Taq II, Takaka, New Zealand) and analyzed in the real-time system, as described by An et al. (2012). Reactions were initiated with an initial incubation at $50{ }^{\circ} \mathrm{C}$ for $2 \mathrm{~min}$ and $95^{\circ} \mathrm{C}$ for $10 \mathrm{~min}$, followed by 40 cycles of $95^{\circ} \mathrm{C}$ for $15 \mathrm{~s}$, and $60^{\circ} \mathrm{C}$ for $60 \mathrm{~s}$. Three biologic replicates and four technical replicates were assayed for all PCRs. The Livak method (Livak and Schmittigen, 2001) was employed to calculate the gene relative expression level.

Statistical analysis. All experiments were carried out in triplicate, and data were tested for differences using analysis of variance, and mean separation within samples by Duncan's multiple range test (SAS version 8.1; SAS Institute, Cary, NC).

\section{Results}

GROWTH PERFORMANCE OF MANDARIN GRAFTED ON 'ZHIQUE' AND TRIFOLIATE ORANGE. Leaves of 'Miyagawa Wase' Satsuma mandarin grafted on 'Zhique' rootstock were green and plants displayed vigorous growth (Fig. 1A). By contrast, 'Miyagawa Wase' grafted on trifoliate orange rootstock showed obvious interveinal chlorosis in young leaves (Fig. 1C). This is a common symptom of Fe-deficiency chlorosis, so the basic soil properties were measured to confirm our speculation. Soil $\mathrm{pH}$ and the concentration of $\mathrm{Ca}$ were much higher than the optimum concentration, whereas the $\mathrm{N}$ and Fe concentration were lower than the critical soil test values (Obreza and Morgan, 2008) (Supplemental Table 1). Leaf nutrient analysis of 10 elements (N, P, K, Ca, Mg, Fe, Mn, Cu, Zn, and B) showed that only the concentration of $\mathrm{Fe}$ was higher in 'Miyagawa Wase'/'Zhique' than in 'Miyagawa Wase'/ trifoliate orange (Supplemental Table 2), though it was still in the normal thresholds in the two samples (Koo et al., 1984).

LEAF CHLOROPHYLL CONCENTRATION AND CHLOROPLAST ULTRASTRUCTURE. Leaf chlorophyll concentration of green leaves of 'Miyagawa Wase'/trifoliate orange and 'Miyagawa Wase'/'Zhique' showed no significant difference in Chl a concentration, but Chl b concentration of 'Miyagawa Wase'/ trifoliate orange leaves was significantly lower than that of 'Miyagawa Wase'/'Zhique' leaves (Fig. 3). Within the 'Miyagawa Wase'/trifoliate orange samples, Chl a and $\mathrm{Chl} b$ in chlorotic leaves were $17 \%$ and $20 \%$ of what was found in green leaves, respectively (Fig. 3). TEM observations of chloroplasts from green leaves of 'Miyagawa Wase'/'Zhique' samples contained abundant starch granules, whereas chloroplasts from 'Miyagawa Wase'/trifoliate orange leaves had a large number of plastoglobules (Fig. 2E and 2F). Within the 'Miyagawa Wase'/trifoliate orange samples, the grana thylakoids were significantly decreased in the chlorotic leaves in comparison with the green leaves (Fig. 2D and 2E).

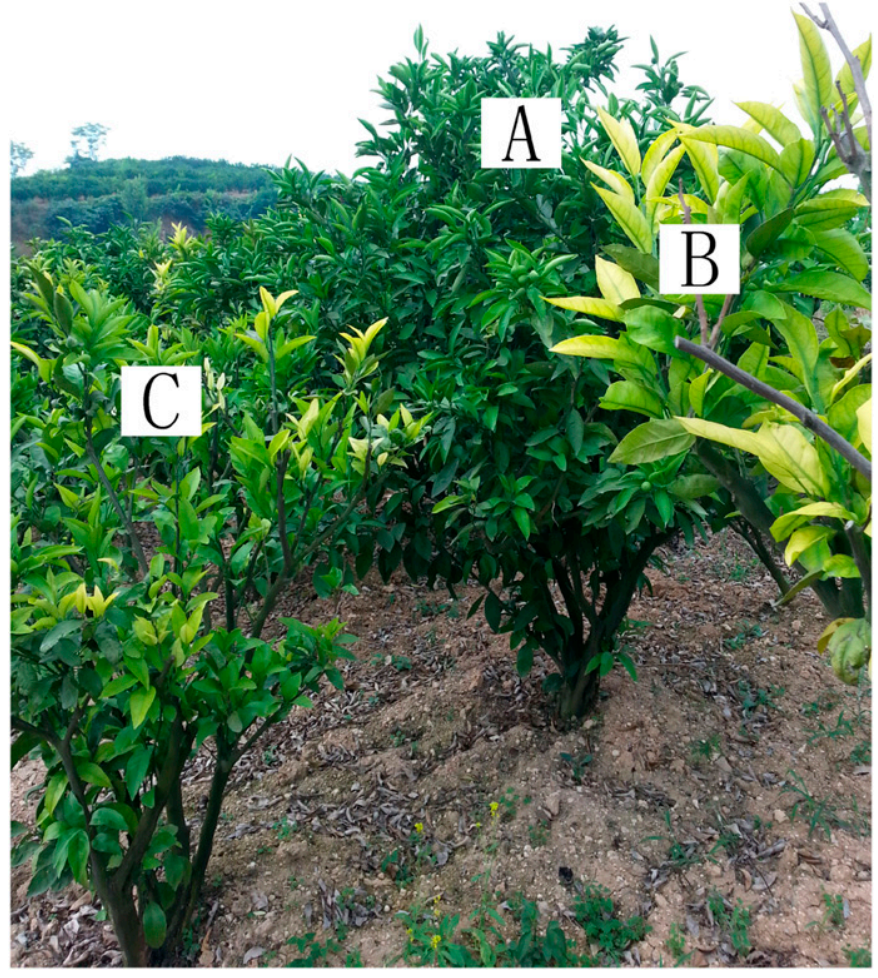

Fig. 1. 'Miyagawa Wase' Satsuma mandarin grafted on (A) 'Zhique' citrus rootstock and $(\mathbf{B}, \mathbf{C})$ trifoliate orange rootstock, respectively.

Fe concentration analysis. Total $\mathrm{Fe}$ and cell wall $\mathrm{Fe}$ concentrations were not significantly different between the 'Miyagawa Wase'/'Zhique' and 'Miyagawa Wase'/trifoliate orange roots, whereas ferrous $\mathrm{Fe}$ concentration in roots of 'Miyagawa Wase'/'Zhique' was significantly higher than that of 'Miyagawa Wase'/trifoliate orange (Fig. 4B). Total $\mathrm{Fe}$, cell wall $\mathrm{Fe}$, and ferrous $\mathrm{Fe}$ concentrations were significantly higher in 'Miyagawa Wase'/'Zhique' leaves than in 'Miyagawa Wase'/trifoliate orange leaves; within the 'Miyagawa Wase'/trifoliate orange samples, total Fe and ferrous Fe were significantly higher in green leaves than in chlorotic leaves, but the cell wall Fe showed no difference (Fig. 5).

Gene eXPRession AnAlysis. 'Miyagawa Wase' Satsuma mandarin grafted on 'Zhique' rootstock had significantly higher Fe concentrations than those grafted on trifoliate orange rootstock, suggesting that the rootstocks have different Feuptake efficiency in calcareous soils. The transcription expression of key genes related to Fe uptake (FIT, HA, FRO, IRT1, $I R T 2$, and $N R A M P$ ) were examined in the roots of 'Miyagawa Wase'/'Zhique' and 'Miyagawa Wase'/trifoliate orange by RTPCR (Fig. 6). We found much higher expression of $F I T, H A$, $F R O$, and NRAMP genes in the roots of Zhique, whereas IRT1 and IRT2 showed lower expression in 'Miyagawa Wase'/'Zhique' roots.

\section{Discussion}

'ZHIQUE' ROOTSTOCK IS TOLERANT OF FE DEFICIENCIES IN CAlCAREOUs soils. Extensive interveinal chlorosis of 'Miyagawa Wase' Satsuma mandarins grafted on trifoliate orange rootstock in an orchard with calcareous soils was observed, but 

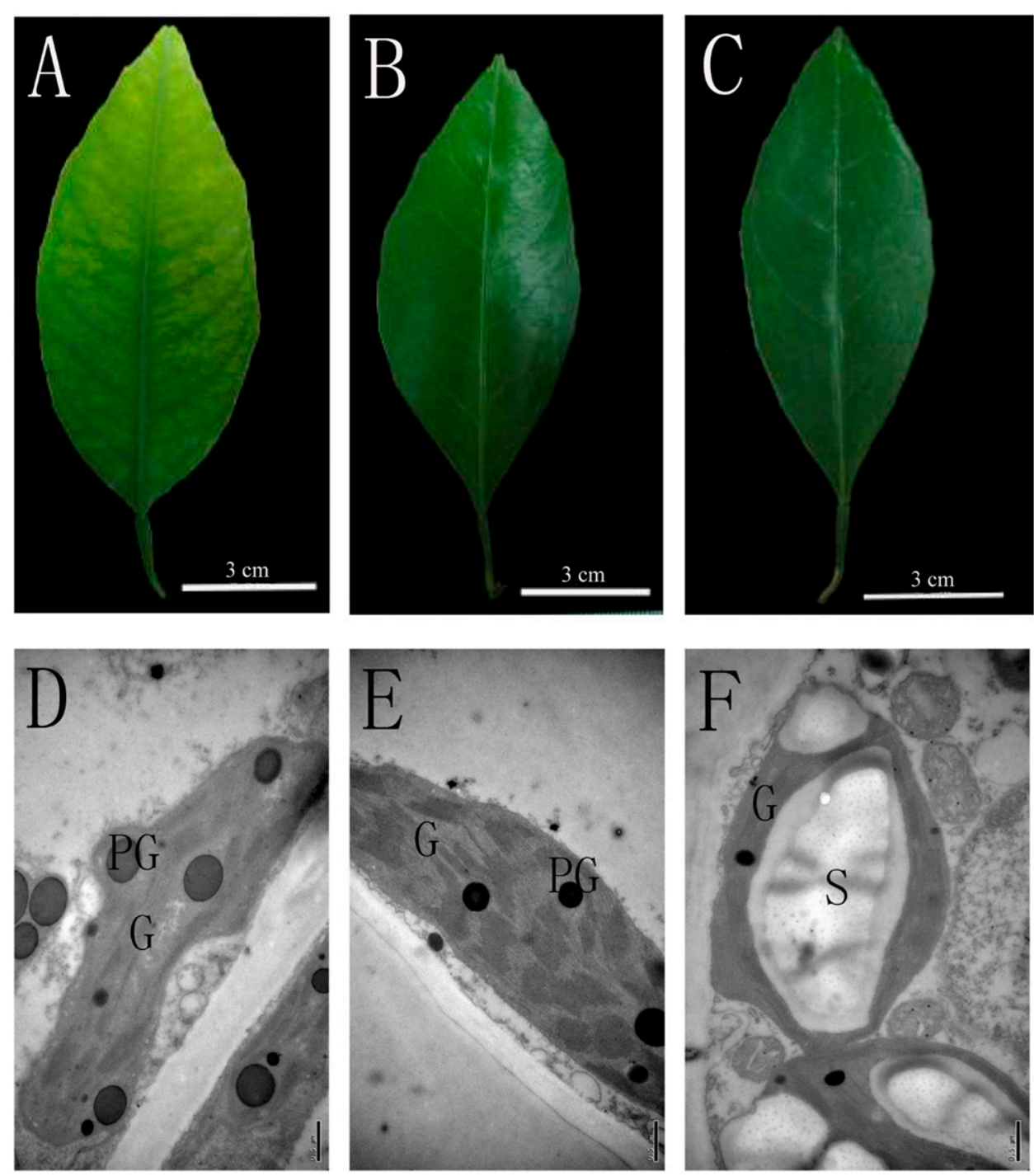

Fig. 2. The chloroplast ultrastructure in leaves of 'Miyagawa Wase' Satsuma mandarin grafted on $(\mathbf{C}, \mathbf{F})$ 'Zhique' citrus rootstock and $(\mathbf{A}, \mathbf{B}, \mathbf{D}, \mathbf{E})$ trifoliate orange rootstock was examined by transmission electron microscopy; $\mathrm{G}=$ grana stack; $\mathrm{PG}=$ plastoglobules; $\mathrm{S}=$ starch granule
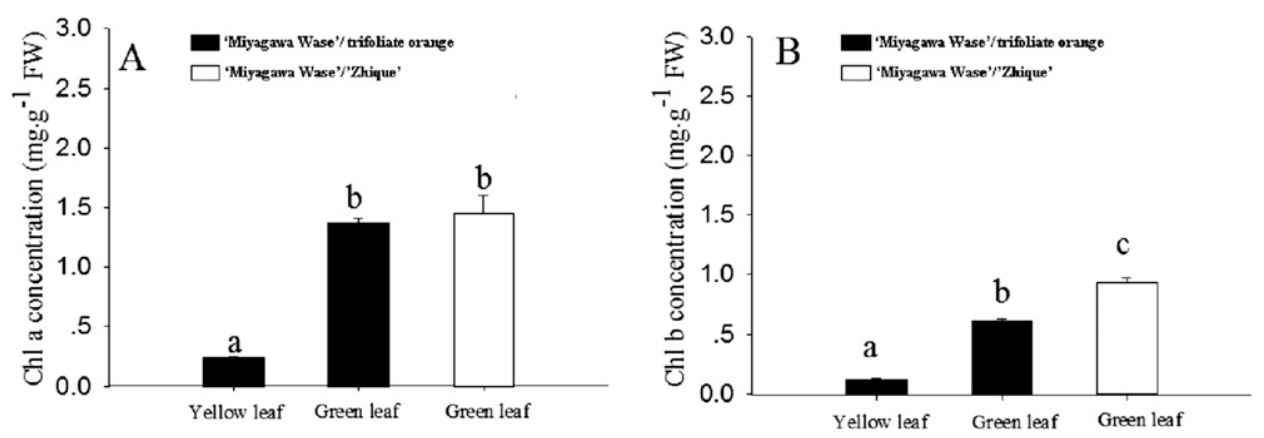

Fig. 3. Concentration of (A) Chl a and (B) Chl b in leaves of 'Miyagawa Wase' Satsuma mandarin grafted on 'Zhique' citrus rootstock and trifoliate orange rootstock. Different letters indicate significant differences within samples via Duncan's multiple range test at $P<0.05[$ mean $\pm \operatorname{SE}(n=3)]$.

'Miyagawa Wase' Satsuma mandarins grafted on 'Zhique' rootstock were healthy and exhibited vigorous growth. Because the interveinal chlorosis mainly occurred on young leaves, we speculated it might be caused by Fe deficiency based on previously described symptoms of Fe deficiency in citrus. The soil $\mathrm{pH}$ (7.62) and $\mathrm{Ca}$ content $(6000$ $\left.\mathrm{mg} \cdot \mathrm{kg}^{-1}\right)$ greatly exceeded the normal threshold $(\mathrm{pH} 5.50-6.50 ; \mathrm{Ca}$ $1000-2000 \mathrm{mg} \cdot \mathrm{kg}^{-1}$ ) for citrus growth (Supplemental Table 1) by analysis of soil properties, which might in turn lower the availability of soil Fe (Mengel and Geurtzen, 1986; Mengel et al., 1984). N and Fe content in soils were both below the normal thresholds, and $\mathrm{N}$ deficiency also results in chlorosis symptoms. However, $\mathrm{N}$ content in leaves of 'Miyagawa Wase'/trifoliate orange was higher than 'Miyagawa Wase'/ 'Zhique' by leaf tissue nutrient analysis; chlorosis symptom typically only on older leaves because $\mathrm{N}$ is easily translocated within the plant (Vesk et al., 1966), thus we could exclude the idea that the chlorosis was caused by $\mathrm{N}$ deficiency. Leaf nutrient analysis also revealed that out of 10 elements $(\mathrm{N}, \mathrm{P}, \mathrm{K}, \mathrm{Ca}, \mathrm{Mg}$, $\mathrm{Fe}, \mathrm{Mn}, \mathrm{Cu}, \mathrm{Zn}$, and B), only Fe was much lower in the leaves of 'Miyagawa Wase'/trifoliate orange than in 'Miyagawa Wase'/'Zhique'. Despite this, concentrations were within the normal range in both 'Miyagawa Wase'/trifoliate orange and 'Miyagawa Wase'/'Zhique' samples. This may be due to immobile $\mathrm{Fe}$ in the vascular tissues of the leaves that contain sufficient $\mathrm{Fe}$ (Jiménez et al., 2009; Tomasi et al., 2009). Taken together, we could conclude that the chlorosis symptom in the leaves of 'Miyagawa Wase'/trifoliate orange was a result of Fe deficiency.

In higher plants, most of the mobilized $\mathrm{Fe}$ is found in chloroplasts, thus Fe deficiency often affects the chloroplast. Fedeficiency--induced chlorophyll reduction damages the structure and functions of the chloroplast, and largely reduces the number of the thylakoid membranes (Soldatini et al., 2000; Spiller and Terry, 1980; Terry and Zayed, 1995). Our hypothesis that the chlorosis was caused by Fe deficiency was further supported by results that the chloroplast ultrastructure was impaired, chlorophyll concentration was significantly reduced, and the Fe concentrations were significantly decreased in the chlorotic leaves. Compared with 'Miyagawa Wase' grafted on the most widely used rootstock trifoliate orange, the 'Miyagawa Wase' on 'Zhique' rootstock showed no 

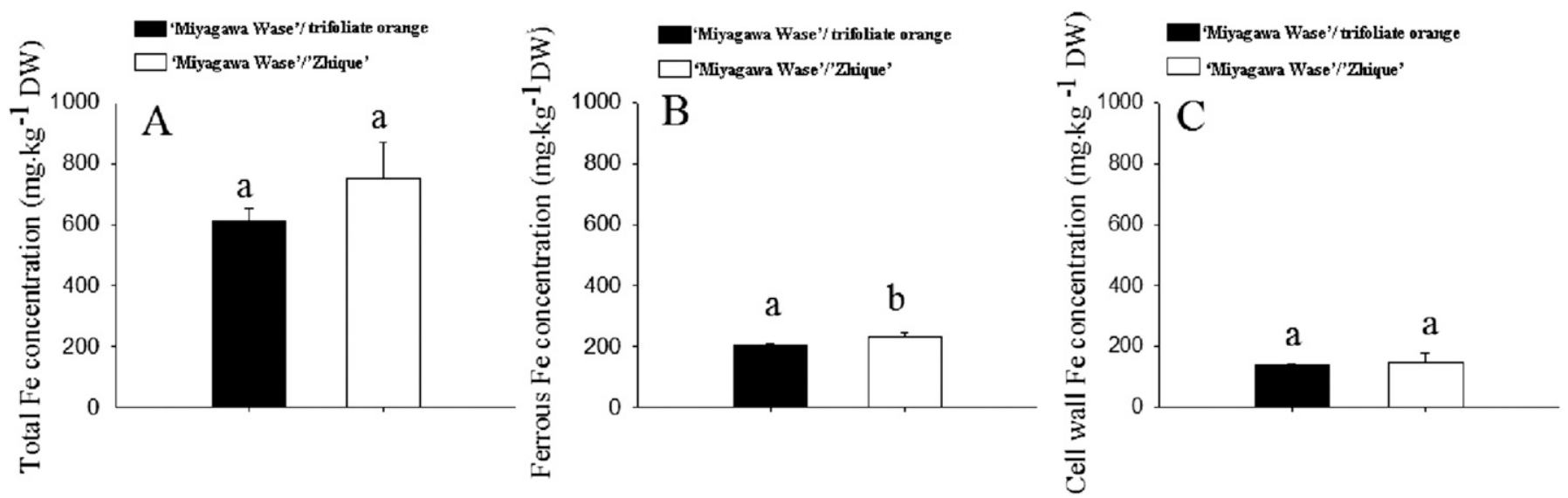

Fig. 4. Iron concentration in roots of 'Miyagawa Wase' Satsuma mandarin grafted on 'Zhique' citrus rootstock and trifoliate orange rootstock. Different letters indicate significant differences within samples via Duncan's multiple range test at $P<0.05$ [mean $\pm \operatorname{SE}(n=3)]$.
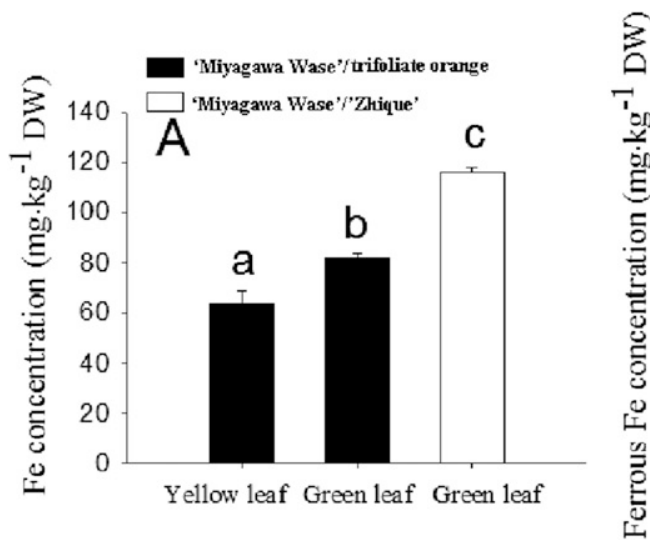

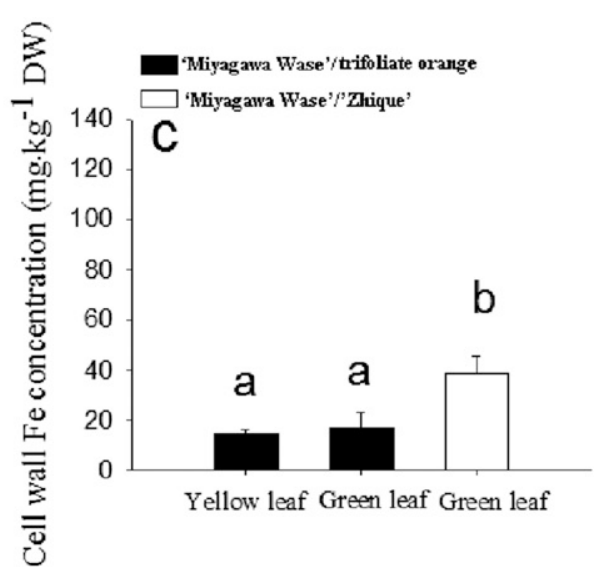

Fig. 5. Iron concentration in leaves of 'Miyagawa Wase' Satsuma mandarin grafted on 'Zhique' citrus rootstock and trifoliate orange rootstock. Different letters indicate significant differences within samples via Duncan's multiple range test at $P<0.05$ [mean $\pm \mathrm{SE}(n=3)]$.

symptoms of Fe deficiency, the chloroplast ultrastructure was intact, and the chlorophyll and Fe concentrations were significantly higher compared with the trifoliate orange samples. According to Jelali et al. (2011), the integrity of the photosynthetic apparatus could be related to the tolerance of Fe deficiency. Therefore, we concluded that under calcareous soil conditions, 'Miyagawa Wase' grafted on 'Zhique' was more tolerant of Fe deficiency than 'Miyagawa Wase' grafted on trifoliate orange due to the different genotypes of citrus rootstocks.

The possible mechanism of the aCclimation to Fe DEFICIENCY IN 'ZHIQUE'. To gain insight into the differences in Fe-uptake capacity between 'Zhique' and trifoliate orange rootstocks, three different forms of $\mathrm{Fe}$ concentration were measured. Total $\mathrm{Fe}$, ferrous $\mathrm{Fe}$, and cell wall $\mathrm{Fe}$ in roots of 'Zhique' were higher than trifoliate orange, but only the ferrous Fe showed significant difference between the two samples. Our results were a little bit different from a previous report that the total $\mathrm{Fe}$ concentration of tolerant citrus rootstock was significant higher than sensitive one (Martínez-Cuenca et al., 2013a), which might be due to our samples being collected under field conditions. Ferrous Fe was significantly higher in leaves in the 'Zhique' grafted samples. Consistent with this result, isotopic tracing experiments found that ferrous Fe uptake in roots and its transport from roots to shoots were much higher in Fe-deficiencytolerant citrus rootstocks than in Fe-deficiency-susceptible rootstocks under Fe deficient conditions (Manthey et al., 1994). Combined with the chloroplast structure and chlorophyll concentration results, these findings of Fe concentration determination indicate that the ferrous Fe plays an important role in the chlorophyll biosynthesis. The difference of Fe-deficiency responses in different citrus genotypes could be related to leaf $\mathrm{Fe}$ status, which is in accordance with previously reports in other species such as tomato [Solanum lycopersicum L.(Dasgan et al., 2003)], maize [Zea mays L. (Tewari et al., 2005)], and grapevine [Vitis vinifera L. (Ksouri et al., 2006)]. It is suggested that the uptake capacity of ferrous $\mathrm{Fe}$ might be an important factor affecting the acclimation of citrus plants to Fe deficiency. Our findings indicate that ferrous $\mathrm{Fe}$ concentration may be a crucial index to assess the Fe-deficiency tolerance capacity of citrus rootstocks and might be used to diagnose Fe-deficiency symptom in citrus cultivation management.

The Fe-uptake capacity of 'Zhique' and trifoliate orange was further evaluated by investigating the transcription levels of several genes (FIT, HA, FRO, IRTI/2, and NARMP) involving Fe uptake in roots. The FIT coding a central transcription factor can regulate Fe-uptake-related genes, including the $H A, F R O$, and IRT1/2 genes (Colangelo and Guerinot, 2004). The FIT gene was significantly higher in 'Zhique' roots, indicating that the FIT-mediated Fe-uptake-related genes expression was higher than that in trifoliate orange roots under $\mathrm{Fe}$ deficient 


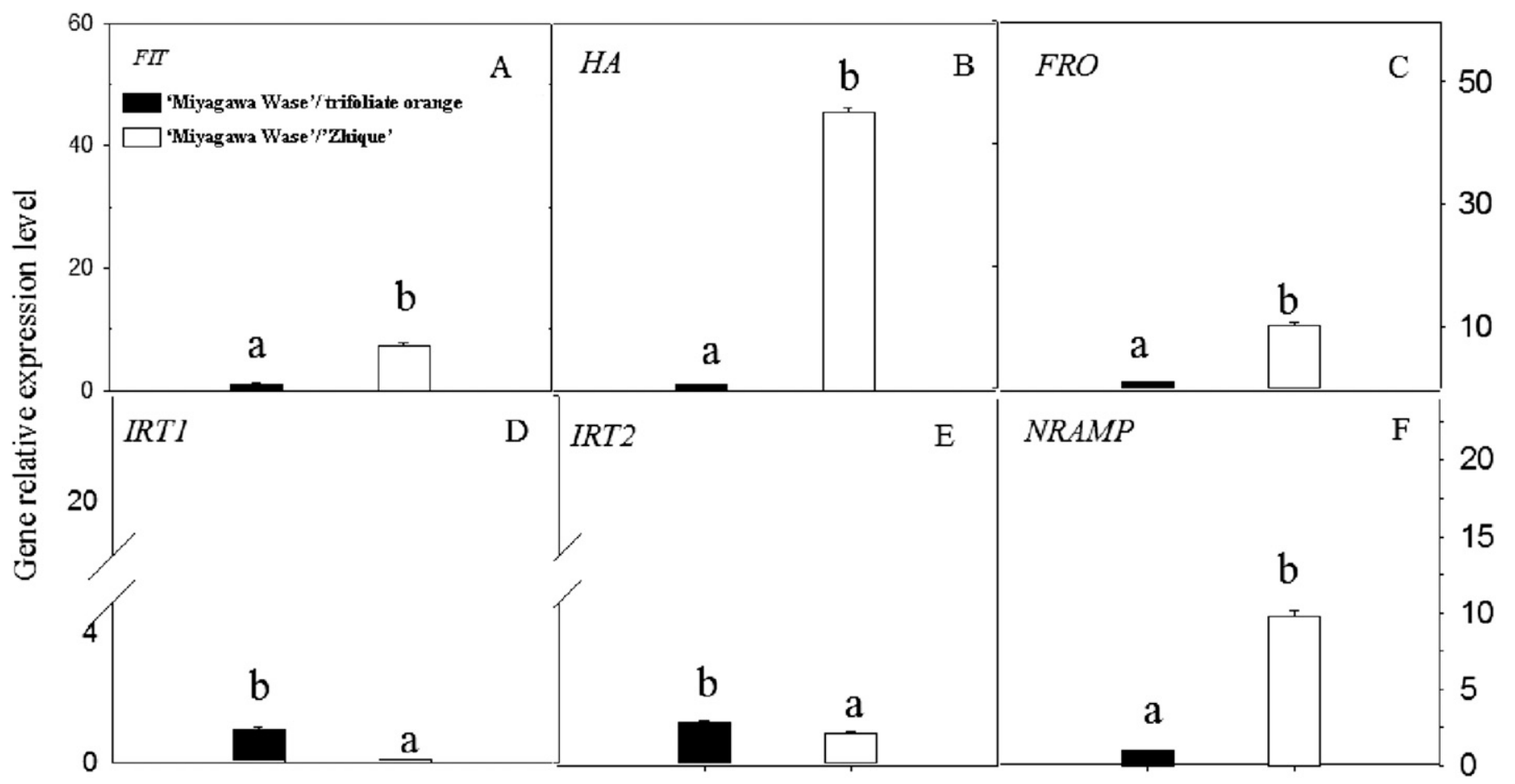

Fig. 6. Relative expression of (A) FIT, (B) HA, (C) FRO, (D) IRT1, (E) IRT2, and (F) NRAMP genes in roots of 'Miyagawa Wase' Satsuma mandarin grafted on 'Zhique' citrus rootstock and trifoliate orange rootstock measured by real-time reverse transcription polymerase chain reaction analysis. Different letters indicate significant differences within samples via Duncan's multiple range test at $P<0.05$ [mean $\pm \mathrm{SE}(n=3)]$.

conditions. Correspondingly, in the deficiency-tolerant 'Zhique' roots, higher transcription expression was observed for the downstream genes of FIT, $H A$, and $F R O$, which are involved in Fe uptake by acidifying the rhizosphere and reducing ferric Fe (Martínez-Cuenca et al., 2013a, 2013b), respectively. However, it was surprising that the transcription expressions of two other downstream genes, IRT1 and IRT2, were much lower in 'Zhique' roots compared with trifoliate orange roots. It appears that IRT1 or IRT2 may not be critical for the Fe-deficiencytolerant responses in the 'Zhique' rootstock. In addition, NRAMP3 encoding multispecific vacuolar metal transporter (Thomine et al., 2003) also showed higher expression pattern in 'Zhique' roots compared with trifoliate orange roots, This suggested that the NRAMP3-mediated intracellular metal homeostasis of $\mathrm{Fe}$ might be different in the two rootstocks.

In conclusion, the Fe-deficiency-tolerant rootstock 'Zhique' appears to preserve sufficient total- and/or ferrous-Fe in roots and leaves so that it can maintain intact chlorophyll structure for photosynthetic activity under conditions, which cause Fedeficiency symptoms in other genotypes; transcription analysis of Fe-deficiency-responsive genes indicated that 'Zhique' might have more capacity in Fe uptake in alkaline soils. The 'Zhique' rootstock tested in this study provides a novel material for studying the mechanisms of Fe-deficiency responses and appears to be a Fe-deficiency-tolerant rootstock suitable for citrus cultivation in alkaline soils.

\section{Literature Cited}

Àlvarez-Fernàndez, A., J. Abadía, and A. Abadía. 2006. Iron nutrition in plants and rhizospheric microorganisms. Springer-Verlag, Berlin, Germany.

An, J.C., Y.Z. Liu, C.Q. Yang, G.F. Zhou, Q.J. Wei, and S.A. Peng. 2012. Isolation and expression analysis of CiNIP5, a citrus boron transport gene involved in tolerance to boron deficiency. Sci. Hort. 142:149-154.

Bacaicoa, E. and J.M. García-Mina. 2009. Iron efficiency in different cucumber cultivars: The importance of optimizing the use of foliar iron. J. Amer. Soc. Hort. Sci. 134:405-416.

Bao, S. 2000. Soil agrochemical analysis. 3rd ed. China Agriculture Press, Beijing, China.

Barberon, M., E. Zelazny, S. Robert, G. Conéjéro, C. Curie, J. Friml, and G. Vert. 2011. Monoubiquitin-dependent endocytosis of the iron-regulated transporter 1 (IRT1) transporter controls iron uptake in plants. Proc. Natl. Acad. Sci. USA 108:E450-E458.

Castle, W.S., J. Nunnallee, and J.A. Manthey. 2009. Screening citrus rootstocks and related selections in soil and solution culture for tolerance to low-iron stress. HortScience 44:638-645.

Clemens, S. 2001. Molecular mechanisms of plant metal tolerance and homeostasis. Planta 212:475-486.

Colangelo, E.P. and M.L. Guerinot. 2004. The essential basic helixloop-helix protein FIT1 is required for the iron deficiency response. Plant Cell 16:3400-3412.

Curie, C., J. Alonso, M.L. Jean, J. Ecker, and J. Briat. 2000. Involvement of NRAMP1 from Arabidopsis thaliana in iron transport. Biochem. J. 347:749-755.

Dasgan, H.Y., L. Ozturk, K. Abak, and I. Cakmak. 2003. Activities of iron-containing enzymes in leaves of two tomato genotypes differing in their resistance to Fe chlorosis. J. Plant Nutr. 26:1997-2007.

Dell'Orto, M., S. Santi, P. De Nisi, S. Cesco, Z. Varanini, G. Zocchi, and R. Pinton. 2000. Development of Fe-deficiency responses in cucumber (Cucumis sativus L.) roots: Involvement of plasma membrane $\mathrm{H}^{+}$-ATPase activity. J. Expt. Bot. 51:695-701.

Fageria, N., V. Baligar, and R. Clark. 2002. Micronutrients in crop production. Adv. Agron. 77:185-268.

Ishii, T., T. Matsunaga, P. Pellerin, M.A. O'Neill, A. Darvill, and P. Albersheim. 1999. The plant cell wall polysaccharide rhamnogalacturonan II self-assembles into a covalently crosslinked dimer. J. Biol. Chem. 274:13098-13104. 
Jelali, N., B.S. Imen, M. Wissal, D. Silvia, Z. Graziano, and G. Mohamed. 2011. Comparison of three pea cultivars (Pisum sativum) regarding their responses to direct and bicarbonate-induced iron deficiency. Sci. Hort. 129:548-553.

Jiménez, S., F. Morales, A. Abadía, J. Abadía, M.A. Moreno, and Y. Gogorcena. 2009. Elemental 2-D mapping and changes in leaf iron and chlorophyll in response to iron re-supply in iron-deficient GF 677 peach-almond hybrid. Plant Soil 315:93-106.

Kaiser, B.N., S. Moreau, J. Castelli, R. Thomson, A. Lambert, S. Bogliolo, A. Puppo, and D.A. Day. 2003. The soybean NRAMP homologue, GmDMT1, is a symbiotic divalent metal transporter capable of ferrous iron transport. Plant J. 35:295-304.

Kim, S.A. and M.L. Guerinot. 2007. Mining iron: Iron uptake and transport in plants. FEBS Lett. 581:2273-2280.

Koo, R.C.J., C.A. Anderson, I. Stewart, D.P.H. Tucker, D.V. Calvert, and H.K. Wutscher. 1984. Recommended fertilizers and nutritional sprays for citrus. Florida Agr. Expt. Sta. Bul. 536D.

Ksouri, R., S. M'rah, M. Gharsalli, and M. Lachaâl. 2006. Biochemical responses to true and bicarbonate-induced iron deficiency in grapevine genotypes. J. Plant Nutr. 29:305-315.

Licciardello, C., B. Torrisi, M. Allegra, F. Sciacca, G. Roccuzzo, F. Intrigliolo, G.R. Recupero, P. Tononi, M. Delledonne, and V. Muccilli. 2013. A transcriptomic analysis of sensitive and tolerant citrus rootstocks under natural iron deficiency conditions. J. Amer. Soc. Hort. Sci. 138:487-498.

Livak, K. and T. Schmittgen. 2001. Analysis of relative gene expression data using real-time quantitative PCR and the 2 (-Delta Delta C (T)) method. Methods 25:402-408.

Llorente, S., A. Leon, A. Torrecillas, and C. Alcaraz. 1976. Leaf iron fractions and their relation with iron chlorosis in citrus. Agrochimica 20:204-212.

Manthey, J., D. McCoy, and D. Crowley. 1994. Stimulation of rhizosphere iron reduction and uptake in response to iron deficiency in citrus rootstocks. Plant Physiol. Biochem. 32:211-215.

Martínez-Cuenca, M.-R., M.Á. Forner-Giner, D.J. Iglesias, E. Primo-Millo, and F. Legaz. 2013a. Strategy I responses to Fe-deficiency of two Citrus rootstocks differing in their tolerance to iron chlorosis. Sci. Hort. 153:56-63.

Martínez-Cuenca, M.-R., F. Legaz, M.Á. Forner-Giner, E. Primo-Millo, and D.J. Iglesias. 2013b. Bicarbonate blocks iron translocation from cotyledons inducing iron stress responses in Citrus roots. J. Plant Physiol. 170:899-905.

Mengel, K., M.T. Breininger, and W. Bübl. 1984. Bicarbonate, the most important factor inducing iron chlorosis in vine grapes on calcareous soil. Plant Soil 81:333-344.

Mengel, K. and G. Geurtzen. 1986. Iron chlorosis on calcareous soils. Alkaline nutritional condition as the cause for the chlorosis. J. Plant Nutr. 9:161-173.

Morales, F., A. Abadía, and J. Abadía. 1991. Chlorophyll fluorescence and photon yield of oxygen evolution in iron-deficiency sugar beet (Beta vulgaris L.) leaves. Plant Physiol. 97:886-893.

Morales, F., A. Abadía, R. Belkhodja, and J. Abadía. 1994. Iron deficiency-induced changes in the photosynthetic pigmento composition of field-grown pear (Pyrus communis L.) leaves. Plant Cell Environ. 17:1153-1160.

Nozoye, T., S. Nagasaka, T. Kobayashi, M. Takahashi, Y. Sato, Y. Sato, N. Uozumi, H. Nakanishi, and N.K. Nishizawa. 2011. Phytosiderophore efflux transporters are crucial for iron acquisition in graminaceous plants. J. Biol. Chem. 286:5446-5454.

Obreza, T. and K. Morgan. 2008. Nutrition of Florida citrus trees. Univ. Florida, Inst. Food Agr. Sci. SL 253.
Oserkowsky, J. 1933. Quantitative relation between chlorophyll and iron in green and chlorotic pear leaves. Plant Physiol. 8:449-468.

Pestana, M., A. de Varennes, J. Abadía, and E.A. Faria. 2005. Differential tolerance to iron deficiency of citrus rootstocks grown in nutrient solution. Sci. Hort. 104:25-36.

Rashid, A. and J. Ryan. 2004. Micronutrient constraints to crop production in soils with Mediterranean-type characteristics: A review. J. Plant Nutr. 27:959-975.

Robinson, N.J., C.M. Procter, E.L. Connolly, and M.L. Guerinot. 1999. A ferric-chelate reductase for iron uptake from soils. Nature 397:694-697.

Rombolà, A.D. and M. Tagliavini. 2006. Iron nutrition in plants and rhizospheric microorganisms. Springer-Verlag, Berlin, Germany.

Römheld, V. and H. Marschner. 1986. Evidence for a specific uptake system for iron phytosiderophores in roots of grasses. Plant Physiol. 80:175-180.

Schmidt, W. 1999. Review mechanisms and regulation of reductionbased iron uptake in plants. New Phytol. 141:1-26.

Shenker, M. and Y. Chen. 2005. Increasing iron availability to crops: Fertilizers, organo-fertilizers, and biological approaches. Soil Sci. Plant Nutr. 51:1-17.

Soldatini, G.F., M. Tognini, A. Castagna, B. Baldan, and A. Ranieri. 2000. Alterations in thylakoid membrane composition induced by iron starvation in sunflower plants. J. Plant Nutr. 23:1717-1732.

Spiller, S. and N. Terry. 1980. Limiting factors in photosynthesis II. Iron stress diminishes photochemical capacity by reducing the number of photosynthetic units. Plant Physiol. 65:121-125.

Storey, R. and M. Treeby. 2002. Nutrient uptake into navel oranges during fruit development. J. Hort. Sci. Biotechnol. 77:91-99.

Tagliavini, M. and A.D. Rombolà. 2001. Iron deficiency and chlorosis in orchard and vineyard ecosystems. Eur. J. Agron. 15:71-92.

Terry, N. and A.M. Zayed. 1995. Iron nutrition in soils and plants. Kluwer Academic Publishers, Dordrecht, The Netherlands.

Tewari, R.J., P. Kumar, and N.S.N. Parma. 2005. Signs of oxidative stress in the chlorotic leaves of iron starved plants. Plant Sci. 169:1037-1045.

Thomine, S., F. Lelièvre, E. Debarbieux, J.I. Schroeder, and H. Barbier-Brygoo. 2003. AtNRAMP3, a multispecific vacuolar metal transporter involved in plant responses to iron deficiency. Plant J. 34:685-695.

Tomasi, N., C. Rizzardo, R. Monte, S. Gottardi, N. Jelali, R. Terzano, and S. Cesco. 2009. Micro-analytical, physiological and molecular aspects of $\mathrm{Fe}$ acquisition in leaves of $\mathrm{Fe}$-deficient tomato plants re-supplied with natural Fe-complexes in nutrient solution. Plant Soil 325:25-38.

Vesk, M., J. Possingham, and F. Mercer. 1966. The effect of mineral nutrient deficiencies on the structure of the leaf cells of tomato, spinach, and maize. Austral. J. Bot. 14:1-18.

Wu, G.A., S. Prochnik, J. Jenkins, J. Salse, U. Hellsten, F. Murat, X. Perrier, M. Ruiz, S. Scalabrin, J. Terol, M.A. Takita, K. Labadie, J. Poulain, A. Couloux, K. Jabbari, F. Cattonaro, C.D. Fabbro, S. Pinosio, A. Zuccolo, J. Chapman, J. Grimwood, F.R. Tadeo, L.H. Estornell, J.V. Muñoz-Sanz, V. Ibanez, A. Herrero-Ortega, P. Aleza, J. Pérez-Pérez, D. Ramón, D. Brunel, F. Luro, C. Chen, W.G. Farmerie, B. Desany, C. Kodira, M. Mohiuddin, T. Harkins, K. Fredrikson, P. Burns, A. Lomsadze, M. Borodovsky, G. Reforgiato, J. Freitas-Astúa, F. Quetier, L. Navarro, M. Roose, P. Wincker, J. Schmutz, M. Morgante, M.A. Machado, M. Talon, O. Jaillon, P. Ollitrault, F. Gmitter, and D. Rokhsar. 2014. Sequencing of diverse mandarin, pummelo and orange genomes reveals complex history of admixture during citrus domestication. Nat. Biotechnol. 32:656-662. 
Supplemental Table 1. Physicochemical properties of the calcareous soil in citrus orchard in the Chenggu county of Shaanxi province, China.

\begin{tabular}{lcr}
\hline Analysis index & Mean $\pm \mathrm{SE}$ & Normal thresholds \\
\hline $\mathrm{pH}$ & $7.62 \pm 0.18$ & $5.50-6.50$ \\
Organic matter $\left(\mathrm{mg} \cdot \mathrm{kg}^{-1}\right)$ & $16,870 \pm 1.71$ & $15,000-30,000$ \\
$\mathrm{~N}\left(\mathrm{mg} \cdot \mathrm{kg}^{-1}\right)$ & $72.73 \pm 7.66$ & $100.00-200.00$ \\
$\mathrm{P}\left(\mathrm{mg} \cdot \mathrm{kg}^{-1}\right)$ & $69.08 \pm 11.25$ & $15.00-80.00$ \\
$\mathrm{~K}\left(\mathrm{mg} \cdot \mathrm{kg}^{-1}\right)$ & $180.09 \pm 11.77$ & $100.00-200.00$ \\
$\mathrm{Ca}\left(\mathrm{mg} \cdot \mathrm{kg}^{-1}\right)$ & $6,100 \pm 0.13$ & $1,000-2,000$ \\
$\mathrm{Mg}\left(\mathrm{mg} \cdot \mathrm{kg}^{-1}\right)$ & $190 \pm 0.013$ & $100-300$ \\
$\mathrm{Fe}\left(\mathrm{mg} \cdot \mathrm{kg}^{-1}\right)$ & $7.61 \pm 1.12$ & $10.00-20.00$ \\
$\mathrm{Mn}\left(\mathrm{mg} \cdot \mathrm{kg}^{-1}\right)$ & $8.36 \pm 0.79$ & $5.00-20.00$ \\
$\mathrm{Cu}\left(\mathrm{mg} \cdot \mathrm{kg}^{-1}\right)$ & $0.44 \pm 0.03$ & $0.50-1.00$ \\
$\mathrm{Zn}\left(\mathrm{mg} \cdot \mathrm{kg}^{-1}\right)$ & $1.33 \pm 0.52$ & $1.00-5.00$ \\
$\mathrm{~B}\left(\mathrm{mg} \cdot \mathrm{kg}^{-1}\right)$ & $0.40 \pm 0.068$ & $0.50-1.00$ \\
\hline
\end{tabular}

Supplemental Table 2. Leaf tissue nutrient analysis of 'Miyagawa Wase' Satsuma mandarin grafted on trifoliate orange and 'Zhique' citrus rootstocks based on spring flush leaves from nonfruiting twigs.

\begin{tabular}{|c|c|c|c|c|}
\hline \multirow[b]{2}{*}{ Analysis index } & \multicolumn{2}{|c|}{ 'Miyagawa Wase'/trifoliate orange } & \multirow{2}{*}{$\frac{\text { 'Miyagawa Wase'/‘Zhique' }}{\text { Green leaf }}$} & \multirow[b]{2}{*}{ Normal thresholds } \\
\hline & Yellow leaf & Green leaf & & \\
\hline $\bar{N}(\%)$ & $3.22 \pm 0.13$ & $3.03 \pm 0.25$ & $2.84 \pm 0.17$ & $2.5-2.7$ \\
\hline $\mathrm{P}(\%)$ & $0.14 \pm 0.01$ & $0.11 \pm 0.00$ & $0.11 \pm 0.00$ & $0.12-0.16$ \\
\hline $\mathrm{Ca}(\%)$ & $2.15 \pm 0.15$ & $2.16 \pm 0.10$ & $2.89 \pm 0.53$ & $3.0-4.9$ \\
\hline $\operatorname{Mg}(\%)$ & $0.35 \pm 0.03$ & $0.32 \pm 0.02$ & $0.35 \pm 0.02$ & $0.30-0.49$ \\
\hline $\mathrm{Fe}\left(\mathrm{mg} \cdot \mathrm{kg}^{-1}\right)$ & $69.53 \pm 4.76$ & $82.04 \pm 1.98$ & $116.08 \pm 2.36$ & $60-120$ \\
\hline $\mathrm{Cu}\left(\mathrm{mg} \cdot \mathrm{kg}^{-1}\right)$ & $5.43 \pm 0.77$ & $4.46 \pm 0.83$ & $4.11 \pm 0.49$ & $5-16$ \\
\hline $\mathrm{Zn}\left(\mathrm{mg} \cdot \mathrm{kg}^{-1}\right)$ & $16.89 \pm 2.28$ & $16.64 \pm 3.33$ & $13.94 \pm 0.97$ & $25-100$ \\
\hline $\mathrm{B}\left(\mathrm{mg} \cdot \mathrm{kg}^{-1}\right)$ & $35.67 \pm 3.25$ & $31.63 \pm 2.62$ & $15.83 \pm 1.46$ & $36-100$ \\
\hline
\end{tabular}

Supplemental Table 3. Primer sequences used in the root gene expression studies of 'Miyagawa Wase' Satsuma mandarin grafted on trifoliate orange and 'Zhique' citrus rootstocks.

\begin{tabular}{|c|c|c|c|c|}
\hline Annotation & Code $^{z}$ & Forward/reverse primer $\left(5^{\prime}-3^{\prime}\right)$ & Melting temp $\left({ }^{\circ} \mathrm{C}\right)$ & Predicted product $(\mathrm{bp})$ \\
\hline \multirow[t]{2}{*}{ FIT } & Ciclev10030052m & ATCATCGGAGATGCTGTGTCGT & 61.7 & 136 \\
\hline & & тCTTCTTTGGCTTTTGAATTGG & 59.2 & \\
\hline$H A$ & Ciclev10013498m & TTGGACAGCATACCGAACAGA & 58.9 & 201 \\
\hline \multirow[t]{2}{*}{ FRO } & Ciclev10017436m & GACACCGTGTGCCCATTCTCG & 65.6 & 176 \\
\hline & & TCСАССТТССААТTТTТССАG & 59.3 & \\
\hline ITR 1 & Ciclev10033475m & TTCAGCCACTGCTCTCTCCAA & 60.7 & 121 \\
\hline \multirow[t]{2}{*}{ IRT2 } & Ciclev10030012m & AAAGTGAAGAAGTGGGAACCG & 58.5 & 101 \\
\hline & & AACTGAGTGGAAACAGAGGGC & 58.3 & \\
\hline \multirow[t]{2}{*}{$N R A M P$} & Ciclev10000736m & CGTCGCTCTTCCACAGTCGT & 60.9 & 80 \\
\hline & & TGGGTGATGGGGTTCTTCCT & 61.2 & \\
\hline \multirow[t]{2}{*}{ Actin } & Ciclev10025866m & CCGACCGTATGAGCAAGGAAA & 60 & 200 \\
\hline & & TTCCTGTGGACAATGGATGGA & 60 & \\
\hline
\end{tabular}

${ }^{\mathrm{z}}$ Code refers to $\mathrm{Wu}$ et al. (2014). 